\title{
GEREJA BERMISI MELALUI MEDIA DIGITAL DI ERA REVOLUSI INDUSTRI 4.0
}

\author{
Yosua Feliciano Camerling, Mershy Ch. Lauled, Sarah Citra Eunike \\ Sekolah Tinggi Filsafat Theologia Jaffray Makassar \\ yosuacamerling@gmail.com
}

\begin{abstract}
The purpose is to describe the role of the media in supporting missions in the fourth industrial revolution. The cause of several studies found there are still some digital media users who are not wise in social media. One example is the outbreak of hate speech that plays a more significant role in racial crime in 2019. Also, not a few of the social media and online communication users who use their accounts to slander, bullying, and to spread fake news. For this reason, users must choose wisely in using their social media accounts. The method used is a qualitative description by collecting several references with library studies to produce several explanations that are discussed systematically. The results of this study indicate that the church needs to open up in terms of media development because this will be one of the most effective investments in protecting lives in the era of the fourth industrial revolution. Some strategies in communicating the gospel message that can be done to intensify media services include live streaming sermons, recording sermon videos, updating status through Facebook and Instagram. The conclusion is that media services are beneficial to reach every community that is difficult to achieve. But most of all, media service can aim to speed up the second coming of Jesus Christ. "And this gospel of the kingdom shall be preached in all the world for a witness to all nations; and then shall the end come." (Matthew 24:14 - NKJV).
\end{abstract}

Keywords: media, mission, ministry, gospel, the fourth industrial revolution

\begin{abstract}
Abstrak: Tujuan penelitian ini adalah untuk memaparkan peranan media dalam mendukung pelayanan misi di era revolusi industri 4.0. Sebab dari beberapa penelitian yang dijumpai ternyata masih ada beberapa pengguna media digital yang tidak bijak dalam bersosial media. Salah satu contohnya yaitu mewabahnya ujaran kebencian yang memainkan peran yang lebih besar dalam kejahatan rasial pada tahun 2019. Selain itu, tak sedikit juga dari pengguna media sosial dan sarana komunikasi online lainnya menggunakan akun pribadinya untuk memfitnah, melakukan tindakan bullying, bahkan sampai menyebarkan berita hoax. Untuk itu, para pengguna diharapkan bersikap bijak dalam menggunakan akun media sosialnya. Adapun metode yang digunakan dalam penelitian ini adalah kualitatif deskriptif dengan cara mengumpulkan beberapa rujukan melalui studi kepustakaan sehingga menghasilkan beberapa penjelasan yang dibahas secara sistematis. Hasil dari penelitian ini menunjukkan bahwa gereja perlu membuka diri dalam hal kemajuan perkembangan media sebab ini akan menjadi salah satu ladang pelayanan yang sangat efektif dalam menjangkau jiwa di era revolusi industri 4.0 ini. Beberapa strategi dalam mengkomunikasikan pesan Injil yang dapat dilakukan guna menggiatkan pelayanan media antara lain melalui khotbah live streaming, rekaman video khotbah, update status melalui Facebook dan Instagram. Kesimpulannya ialah pelayanan media sangat berguna untuk menjangkau setiap masyarakat yang sulit untuk dijangkau. Namun yang terutama ialah pelayanan media dapat bertujuan untuk mempercepat kedatangan Yesus Kristus yang kedua kali. "Dan Injil Kerajaan ini akan diberitakan di seluruh dunia menjadi kesaksian bagi semua bangsa, sesudah itu barulah tiba kesudahannya." (Matius 24:14).
\end{abstract}


Kata kunci: media, misi, pelayanan, injil, revolusi industri 4.0

Di era modern saat ini, media mengalami perkembangan yang cukup pesat yang dapat memengaruhi setiap lapisan masyarakat tanpa mengenal batas usia. Salah seorang pemimpin gereja bernama Craig Cabaniss mengatakan bahwa, "Apakah anda di rumah, di mobil, di toko, di restoran, bahkan di pom bensin kita selalu dikelilingi oleh media. Kita tidak bisa lepas dari media. Media sudah menjadi atmosfir kedua kita." (Mahaney et al., 2011, p. 33). Hal tersebut mengindikasikan bahwa media cukup berperan penting dalam kehidupan masyarakat di era ini.

Sebenarnya ini adalah hal yang lumrah terjadi sebab dunia selalu mengalami transformasi. Entah itu transformasi dalam bidang industri, perekonomian, pendidikan bahkan media dan teknologi informasi. Saat ini dunia dikatakan telah memasuki era baru yang dikenal dengan era revolusi industri 4.0. Era ini dikenal karena memiliki ciri khas dalam menggabungkan media digital dan internet dengan industri konvensional. (Prasetyo \& Sutopo, 2018). Memang tak dapat dipungkiri bahwa media digital dan internet sudah menjadi bagian dari kehidupan masyarakat di era ini.

Sebab itu, setiap orang perlu menyadari bahwa media digital dan internet mempunyai dua dampak yang tak terpisahkan. Di satu sisi, media digital dan internet mempunyai dampak yang positif bagi para penggunanya tetapi tak dapat dipungkiri bahwa hal tersebut juga dapat memberikan dampak yang negatif. Salah satu dampak negatif dari media 
digital dan internet yang mewabah akhir-akhir ini ialah hate speech (ujaran kebencian) yang menyebar di media sosial. Bahkan media sosial dan sarana komunikasi online lainnya mulai memainkan peran yang lebih besar dalam kejahatan rasial. (MacAvaney et al., 2019).

Hal ini tentu merupakan tindakan yang tidak terpuji dan tidak bertanggung jawab. Bahkan tak sedikit juga dari para pengguna media sosial menggunakan akun pribadinya hanya untuk memfitnah, melakukan tindakan bullying, bahkan sampai membantu menyebarkan berita hoax. Dari beberapa penelitian menunjukkan bahwa media sosial (Facebook, Twitter, Instagram dan Path) menduduki posisi pertama dalam membantu penyebaran berita hoax yakni mencapai $92,40 \%$. Kemudian disusul oleh aplikasi chatting (Whatsapp, Line, Telegram) di posisi kedua dengan $62,80 \%$ dan situs web di posisi yang terakhir dengan 34,90\%. (Juditha, 2018).

Berdasarkan beberapa masalah yang sudah dipaparkan di atas, penulis merasa bahwa para pengguna media digital dan internet perlu bersikap bijak dalam menggunakan media sosial, termasuk orang percaya yang selama ini hanya menggunakan media sosial sebagai ajang pamer foto, tempat curhat, fitnah dan menyebarkan berita hoax. Orang percaya seyogianya dapat menggunakan kesempatan yang ada untuk membantu menyebarluaskan berita Injil. Sebab bermisi melalui media digital (seperti FB, IG, internet, live streaming) dapat menjadi salah satu ladang 
pelayanan yang sangat efektif dalam menjangkau jiwa di era revolusi industri 4.0 ini.

Salah satu hasil penelitian terhadap penggunaan new media sebagai media komunikasi jemaat GBI Keluarga Allah di Solo menunjukkan bahwa: Dengan new media (Radio Streaming, Live Streaming, Gereja Internet dan Facebook), gereja mampu melayani jemaat dengan tidak terbatas jarak dan waktu. Banyak jemaat merasa diberkati sehingga mereka memiliki kerinduan untuk terus dan terus menggunakan new media gereja, baik radio streaming, live streaming, gereja internet maupun facebook. Bahkan dampaknya sampai menyebar kepada rekan, keluarga, kerabat dan sahabat jemaat. (Okselviana \& Hastjarjo, 2016).

Berdasarkan hal tersebut, Ronda mengatakan bahwa media memang cukup berpengaruh besar dalam hal mengkomunikasikan pesan Injil (Ronda, 2016). Pandangan tersebut juga didukung oleh Pasasa dalam penelitiannya bahwa bermisi melalui media digital dan internet memberi peluang kepada gereja untuk melakukan penjangkauan dengan Injil di manapun mereka berada. (Pasasa, 2015).

Oleh sebab itu, gereja seyogianya perlu mengambil bagian untuk bermisi melalui media digital. Gereja - yang dalam hal ini adalah orang percaya - diharapkan tidak menggunakan media digital untuk memberitakan hal-hal yang tidak penting seperti curhat, gosip dan berita hoax namun berani untuk membagikan pesan Injil di akun media 
sosialnya. Apalagi dunia di mana kita hidup sekarang ini tidak terlepas dari yang media digital dan internet.

Hal ini dapat dibuktikan dari penelitian yang menunjukkan bahwa terdapat 640 juta pengguna jaringan aktif di seluruh dunia. Bahkan Indonesia menduduki urutan kedua dalam catatan penggunaan Facebook terbanyak dan urutan pertama dalam penggunaan Twitter. Kemudian sampai pada tahun 2010 tercatat bahwa ada 57,8 juta pengguna internet di Indonesia dan akan diprediksi menjadi 175 juta pada tahun 2020. (Pratama, 2012). Selain itu, hasil survei yang dilakukan oleh Asosiasi Penyelenggara Jasa Internet Indonesia (APJII) terkait pengguna internet di Indonesia mengalami pertambahan sebanyak 10,12\% pada 2018 dibandingkan tahun sebelumnya yakni mencapai 171,17 juta pengguna dari populasi 264,16 juta jiwa. (Asosiasi Penyelenggara Jasa Internet Indonesia, 2019).

Dengan demikian, gereja perlu membuka diri untuk hal-hal yang berhubungan dengan media digital di era revolusi industri 4.0 ini. Sebab Ravi Zacharias dalam cuitannya di Twitter pernah berkata bahwa: "This generation listens with its eyes \& thinks with its feelings." (Zacharias, 2013). Kutipan ini berarti generasi sekarang mendengar dengan mata mereka dan berpikir dengan perasaan mereka. Untuk itu, gereja perlu menggunakan media digital dalam bermisi sehingga perkataan Yesus Kristus dapat tergenapi: "Dan Injil Kerajaan ini akan diberitakan di seluruh 
dunia menjadi kesaksian bagi semua bangsa, sesudah itu barulah tiba kesudahannya." (Mat. 24:14).

\section{METODE}

Adapun metode yang digunakan dalam penelitian ini adalah kualitatif deskriptif. Metode penelitian ini digunakan untuk meneliti kondisi objek alamiah. Peneliti berperan sebagi instrument kunci, teknik pengumpulan data dilakukan secara trianggulasi (gabungan) dan sumber data yang dipakai dalam penelitian ini adalah lingkungan alamiah. (Pasande \& Tari, 2019).

Prosedur pengumpulan data dalam penelitian ini diperoleh melalui studi kepustakaan (Library Research) yang diambil dari rujukan beberapa buku, jurnal, serta artikel online sehingga menghasilkan beberapa penjelasan yang dibahas dengan sistematis yaitu definisi misi dan media, jenis-jenis media serta data statistik penggunaan media digital di Indonesia. Penjelasan selanjutnya yaitu tujuan bermisi melalui media digital dan internet di era revolusi industri 4.0 dan bentuk pelayanan melalui media digital di era revolusi industri 4.0 yang di dalamnya terbagi atas Khotbah Live Streaming, Rekaman Video Khotbah, Video Kesaksian, Update Status Melalui Facebook dan Instagram.

Adapun prosedur analisis data dalam penelitian ini ialah penulis melakukan observasi terhadap rujukan dari beberapa sumber yang didapat kemudian mereduksi dan memilah data-data yang diperoleh. Selanjutnya, penulis menjelaskan beberapa pemahaman yang penulis 
dapatkan dari sumber-sumber tersebut dan kemudian menyimpulkan pemahaman tersebut. (Camerling \& Wijaya, 2019).

\section{HASIL}

Bermisi melalui media digital dan internet merupakan suatu hal yang cukup beragam. Salah satu jenis yang banyak digunakan oleh penduduk dunia sekarang ialah jenis media audio visual yang dalam hal ini pelayanan melalui media sosial dalam hal mengkomunikasikan atau menyajikan berita Injil. Dalam media sosial ada berbagai macam apikasi yang cukup terkenal di kalangan masyarakat. Contohnya, Facebook, Instagram, Whatsapp, Youtube, Line dan masih banyak lagi.

Melalui aplikasi-aplikasi tersebut, muncullah berbagai macam model pelayanan media digital yang dapat dilakukan oleh gereja sebagai strategi dalam mengkomunikasikan pesan Injil di konteks masa kini. Beberapa contoh yang dapat dilakukan oleh gereja guna menggiatkan pelayanan media, antara lain: Khotbah Live Streaming, Rekaman Video Khotbah, Video Kesaksian, dan juga melalui Update Status.

Namun jika berbicara mengenai media secara khusus media sosial, tentunya hal ini mempunyai kelebihan dan kekurangan dalam penggunaannya. Untuk itu sebelum terjun ke dalam pelayanan media, seseorang perlu memerhatikan beberapa hal ini agar bijak dalam bersosial media. Adapun kelebihan dan kekurangan dari bersosial media yang dapat diperhatikan adalah sebagai berikut. 
Kelebihan dari bersosial media dalam menarik perhatian orang ialah mudah diakses, dapat dijadikan sebagai sarana penginjilan yang praktis, dapat membantu proses pemuridan jarak jauh, mempercepat informasi dan mempermudah komunikasi, mudah bersosialisasi dan mendapatkan teman baru, konten sangat beragam dan inovatif serta memberikan informasi secara global.

Adapun kekurangan media dalam kehidupan sehari-hari ialah menyita waktu, menguras biaya, membuat orang malas, membuat adiksi (narkolema), menimbulkan pertengkaran, menjauhkan yang dekat, menguras baterai handphone, mudahnya tersebar berita hoax. Kiranya beberapa hal ini dapat membuat pengguna sosial media secara khusus orang percaya dapat berhikmat dalam bermisi melalui media digital dan internet untuk bermisi. Sehingga media dan teknologi yang ada pada zaman ini dapat menjangkau yang tak terjangkau bukannya malah menjerumuskan penggunanya kepada hal-hal tidak memuliakan Tuhan.

\section{PEMBAHASAN}

\section{Definisi Misi}

Istilah misi berasal dari teks Alkitab versi Latin missio (pengutusan) yang berasal dari kata kerja bahasa Yunani apostello (mengutus). (Sumarto, 2019). Dalam bahasa Inggris biasanya dikenal dengan istilah mission atau missions. Untuk mission berarti pekerjaan spesifik yang dilakukan oleh gereja atau lembaga gerejawi dalam melaksanakan tugas penjangkauan orang-orang bagi Kristus melalui pelayanan lintas budaya. 
Sedangkan missions jangkauannya lebih luas, mengarah kepada segala sesuatu yang gereja atau lembaga gerejawi lakukan yang merujuk kepada kerajaan Allah. (Camerling \& Wijaya, 2019).

Selain itu, David J. Bosch mengatakan bahwa misi lebih luas dari penginjilan. Evangelisasi adalah misi, tetapi misi tidaklah sekedar evangelisasi. Misi berarti keseluruhan tugas yang telah Allah berikan kepada gereja demi keselamatan dunia, tetapi selalu terkait dengan suatu konteks khusus kuasa jahat, keputusasaan dan ketersesatan. Misi adalah gereja yang diutus ke dalam dunia, untuk mengasihi, melayani, memberitakan, mengajar, menyembuhkan, membebaskan. (Bosch, 2009). Dengan demikian orang percaya perlu memahami dan merespons tugasnya sebagai garam dan terang di dunia yang semakin rusak ini.

Pandangan ini senada dengan pendapat John Stott bahwa misi bukanlah satu kata untuk segala sesuatu yang Gereja kerjakan. Misi menggambarkan lebih dari segala sesuatu yang dilakukan oleh Gereja, yang olehnya ia diutus ke dalam dunia. Misi mencakup wilayah kerja yang rangkap, yakni menjadi "garam dunia" dan "terang dunia". (Stott, 1975). Berdasarkan beberapa pandangan tersebut, dapat diketahui bahwa misi yang sesungguhnya adalah ketika orang percaya dengan aktif melibatkan dirinya meluaskan Kerajaan Allah di muka bumi ini.

\section{Definisi Media}

Secara etimologi, media berasal dari bahasa Latin Medius yang secara harfiah, berarti tengah, koma, perantara, atau pengantar. (Arsyad, 
2013). Berdasarkan hal tersebut, dapat diketahui bahwa media merupakan perantara yang menengahi kedua belah pihak agar sesuatu yang ingin disampaikan dapat dimengerti dengan tepat dan jelas. Media dapat berfungsi untuk menengahi dua pihak sehingga pesan atau informasi dapat tersampaikan dengan baik untuk itu media terletak di antara dua pihak.

Secara terminologinya, menurut Arif Sadiman, media adalah perantara atau pengantar pesan dari pengirim ke penerima pesan. (Sadiman, 1993). Sedangkan menurut AECT (1997) sebuah organisasi yang bergerak dalam teknologi pendidikan dan komunikasi, sebagaimana dikutip oleh Wina Sanjaya dalam bukunya, ia mengartikan media sebagai "segala bentuk yang digunakan untuk proses penyaluran informasi". (Sanjaya, 2014, p. 57). Dengan demikian, media adalah segala bentuk dan saluran yang digunakan sebagai perantara atau pengantar informasi dari pengirim pesan kepada penerima pesan.

\section{Jenis-Jenis Media}

Media terdiri dari tiga jenis. Jenis-jenis media tersebut antara lain terdiri dari: Pertama, media visual. Media ini bisa dilihat, dibaca dan diraba sebab itu jenis media ini mudah ditemui dan dibuat sendiri. Adapun contohnya ialah foto, gambar, majalah, buku, alat peraga dan sebagainya. Kedua, media audio yang hanya bisa didengar saja melalui indera telinga sebagai salurannya. Seperti suara yang dihasilkan oleh sebuah alat musik, radio, CD dan sebagainya. Ketiga, media audio visual. Media ini 
gabungan dari keduanya untuk itu media ini bisa didengar dan dilihat secara bersamaan. Misalnya drama, film, pentas seni dan media yang sekarang menjamur di pasaran seperti handphone dan laptop bahkan internet termasuk media audio visual tetapi lebih lengkap dan menyatukan semua jenis format media disebut sebagai multimedia karena berbagai format ada di dalam internet. (Santoso, 2017).

\section{Data Statistik Penggunaan Media Sosial di Indonesia}

Berdasarkan beberapa jenis media di atas, perlu diketahui bahwa media sosial sangat memegang peranan yang cukup besar di semua kalangan usia. Sebuah penelitian yang dilakukan oleh We Are Social, perusahaan media asal Inggris yang bekerja sama dengan Hootsuite, mengatakan bahwa rata-rata orang Indonesia menghabiskan 3 jam 23 menit dalam sehari untuk mengakses media sosial. Selain itu, dari laporan berjudul "Essential Insights Into Internet, Social Media, Mobile, and ECommerce Use Around The World" yang diterbitkan tanggal 30 Januari 2018, dari total populasi Indonesia sebanyak 265,4 juta jiwa, pengguna aktif media sosialnya mencapai 130 juta dengan penetrasi 49 persen. (Pertiwi, 2018).

Aplikasi WhatsApp, Facebook, Instagram, merupakan aplikasi yang berada di posisi teratas yang paling banyak diunduh. Berdasarkan ratarata trafik situs per bulan, Facebook menjadi media sosial paling banyak dikunjungi dengan capaian lebih dari 1 milyar juta pengunjung perbulan. Pengguna Facebook didominasi golongan usia 18-24 tahun dengan 
presentase 20,4 persennya adalah wanita dan 24,2 persennya adalah pria. Sementara total pengguna aktif Instagram bulanan di Indonesia mencapai 53 juta dengan presentase 49 persen wanita dan 51 persen adalah pria. (Pertiwi, 2018).

Berikut ini beberapa data mengenai statistik penggunaan media sosial:

Gambar 1. Presentase rata-rata orang Indonesia menghabiskan waktu untuk mengakses media sosial. (Pertiwi, 2018).

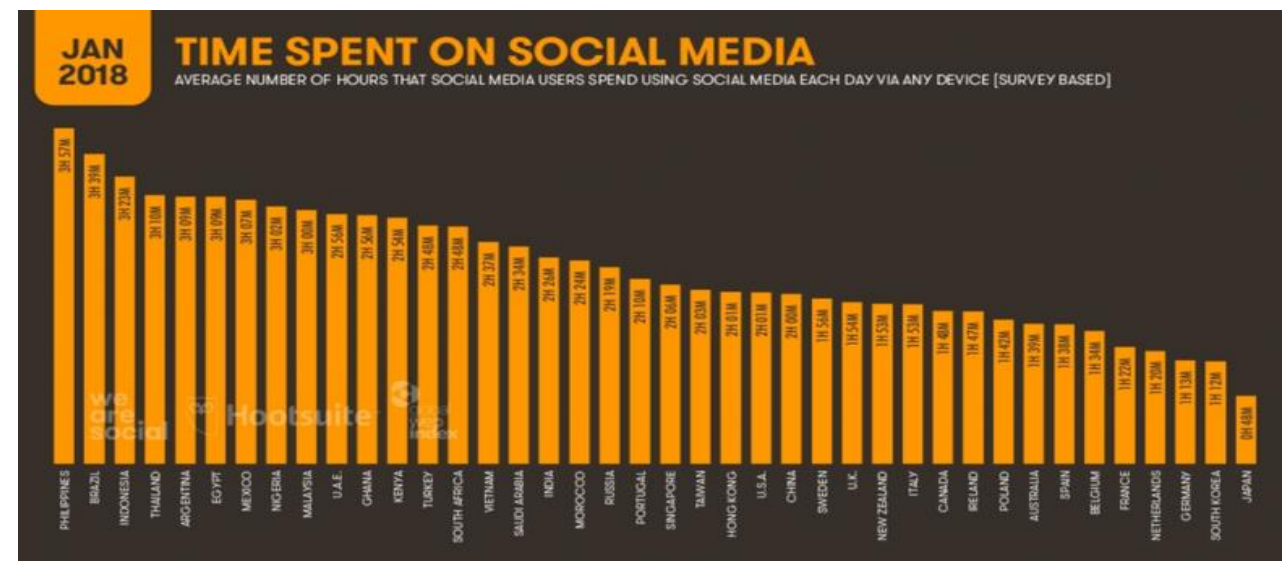

Gambar 2. Presentase media sosial yang paling aktif diakses pengguna media sosial Indonesia Januari 2018. (Pertiwi, 2018).

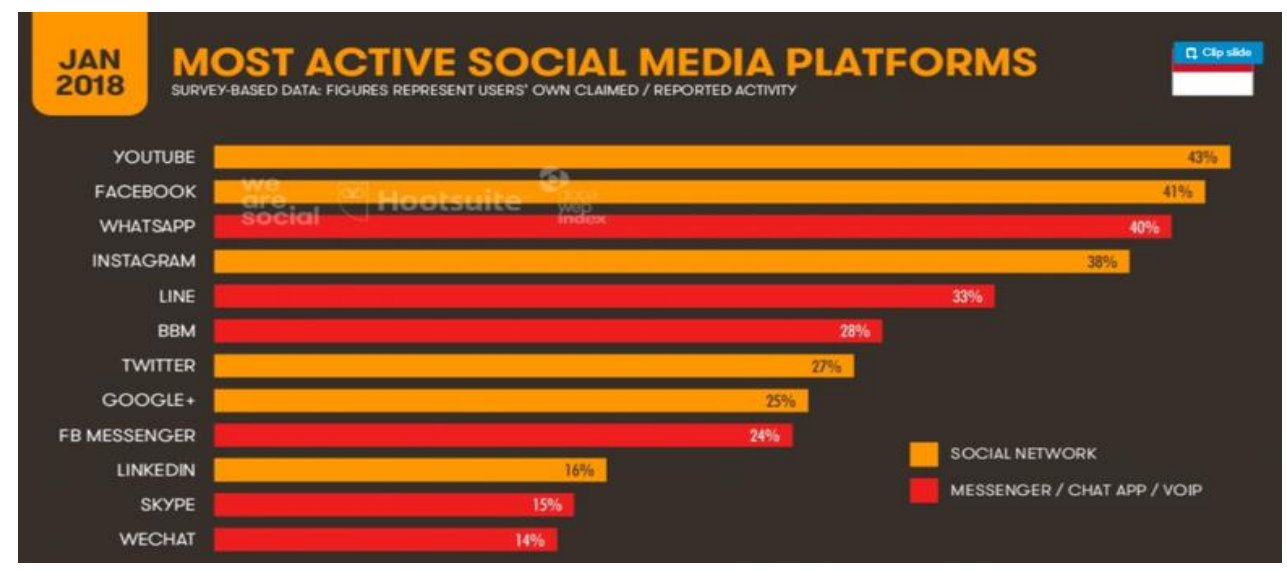

Berdasarkan data statistik yang sudah dipaparkan di atas, dapat disimpulkan bahwa tidak menutup kemungkinan bahwa pelayanan media 
memiliki tujuan yang dapat dikatakan cukup besar dalam bermisi. Sebab dalam data statistik di atas, ditunjukkan bahwa rata-rata orang Indonesia menghabiskan 3 jam 23 menit dalam sehari untuk mengakses media sosial. Itu berarti media (dalam hal ini media sosial) cukup berperan dalam mendukung pelayanan misi di era revolusi industri 4.0.

\section{Tujuan Bermisi Melalui Media Digital Di Era Revolusi Industri 4.0}

Adapun tujuan bermisi melalui media digital di era revolusi industri 4.0, antara lain: Pertama, Bermisi melalui media digital bertujuan untuk memudahkan setiap orang percaya dalam berbagi informasi mengenai berita Injil. Sebagai contoh, ketika ingin berbagi pesan Injil lewat media sosial, hanya dengan beberapa sentuhan di handphone maka berita Injil akan dengan mudah disalurkan ke orang banyak.

Kedua, Bermisi melalui media digital bertujuan untuk menyajikan informasi kepada pembaca maupun pendengar dengan metode yang kreatif dan inovatif. Artinya pesan Injil disampaikan bukan hanya melalui kata-kata saja namun juga melalui beberapa gambar dan animasi bergerak yang dapat menarik perhatian dari orang-orang yang menyaksikannya.

Ketiga, Bermisi melalui media digital bertujuan untuk menjangkau setiap lapisan masyarakat yang sulit untuk dijangkau karena keterbatasan lokasi dan waktu. Maksudnya ialah melalui media, seseorang dapat terhubung dengan individu lainnya yang berbeda lokasi maupun waktu. Melalui media, pesan Injil dengan mudah dapat dijangkau oleh setiap 
orang yang terhubung dengan jaringan internet walaupun berada di pelosok daerah sekalipun.

Keempat, Bermisi melalui media digital untuk membantu mempercepat kedatangan Tuhan (Mat. 24:14). Melalui pelayanan media, seluruh dunia dapat mengakses pesan Injil dengan dunia. Oleh sebab itu, bermisi melalui media digital dapat merupakan alat yang dipakai oleh Tuhan untuk mempercepat kedatangan-Nya. Sebab melalui pelayanan media, Injil Tuhan tidak dapat dibatasi oleh lokasi dan waktu.

\section{Bentuk Pelayanan Melalui Media Digital Di Era Revolusi Industri 4.0}

\section{Khotbah Live Streaming}

Live streaming merupakan salah satu fitur media sosial yang sedang banyak digunakan oleh berbagai kelompok masyarakat bahkan organisasi. Fitur ini dapat ditemukan dalam Facebook, Instagram, dan Youtube. Sekarang ini, banyak gereja juga turut menggunakan fitur live streaming untuk menampilkan siaran langsung selama ibadah berlangsung. Namun perlu diketahui bahwa fitur ini tentu mempunyai pengaruh positif dan negatif bagi para penggunanya. Ketika gereja menggunakan fitur ini maka orang sakit yang tidak dapat pergi ke gereja juga dapat mengikuti ibadah dari awal hingga selesai. Tetapi dampak negatif dari fitur ini juga lambat laun akan membuat orang untuk malas ke gereja dengan alasan dapat menggunakan fitur live streaming di rumah.

Dalam khotbah live streaming, si pengkhotbah tahu dengan persis kepada siapa ia menyampaikan firman Tuhan. Yang menjadi 
permasalahan hanyalah lokasi yang berbeda antara pengkhotbah dan jemaat yang mendengarkan. Jika diibaratkan, khotbah live streaming mirip dengan situasi suatu ibadah di mana jumlah jemaat melebihi kapasitas ruangan, sehingga sebagian duduk di ruangan lain dan menyaksikan khotbah melalui televisi/layar yang dihubungkan ke ruangan utama. Materi dan waktu khotbah sama persis yang berbeda hanyalah tempatnya. Melalui khotbah live streaming dapat mempermudah pesan Injil dapat disampaikan oleh beberapa hamba Tuhan kepada jemaatnya tanpa dibatasi oleh ruang dan waktu. Namun signal internet dan listrik yang menjadi kunci mulus atau tidaknya khotbah ini berlangsung. (Reformed Exodus Community, 2015).

\section{Video Rekaman Khotbah}

Penggunaan rekaman khotbah sebagai substitusi pemberitaan firman Allah secara langsung agak berbeda dengan khotbah live streaming. (Reformed Exodus Community, 2015). Namun yang menjadi kelebihan dengan diadakannya bentuk pelayanan media ini ialah jika suatu ketika seorang hamba Tuhan yang sudah dijadwalkan berhalangan hadir entah karena sakit atau kendala apapun itu (macet, dsb.) dan pada saat yang sama di tempat ibadah tidak ada hamba Tuhan lain yang siap untuk berkhotbah, maka video rekaman khotbah dapat diputar di tengah ibadah. Tentu ini akan menimbulkan persepsi yang berbeda-beda dari jemaat Tuhan yang hadir. Namun jika mengalami kendala seperti yang 
disebutkan di atas, berita Injil tetap dapat disampaikan walaupun hanya melalui video rekaman khotbah.

Bentuk pelayanan melalui media digital ini biasanya digunakan oleh gereja-gereja karismatik yang memiliki banyak cabang gereja dan jam ibadah. Ketika seorang pendeta atau hamba Tuhan yang bertugas berhalangan untuk hadir, tentu ibadah harus tetap berjalan. Video rekaman khotbah dapat diputar dan didengarkan jemaat sebagai bagian dari pelayanan firman. Memang bentuk pelayanan media yang satu ini perlu dipikirkan dengan matang. Persiapan untuk membuat video rekaman khotbah juga perlu menjadi latihan dan bahan pelajaran bagi para hamba Tuhan yang ingin menekuni hal tersebut. Sebab firman Tuhan sendiri berkata: "Tetapi segala sesuatu harus berlangsung dengan sopan dan teratur." (1 Kor. 14:40). Untuk itulah, pelayanan media yang satu ini perlu dipersiapkan dengan sebaik mungkin agar dapat berguna dalam menyampaikan pesan Injil di konteks masa kini.

\section{Video Kesaksian}

Video kesaksian merupakan salah satu strategi yang cukup mudah untuk diviralkan melalui media sosial. Ada banyak aplikasi yang dapat digunakan untuk memposting berbagai video kesaksian yang dapat memberkati banyak orang. Beberapa media sosial yang dapat digunakan untuk memposting video kesaksian ialah melalui Youtube, Instagram, Facebook, Line, bahkan Whatsapp. Di antara semua aplikasi media sosial, yang paling banyak digunakan untuk memposting video ialah melalui 
Youtube yang adalah sebuah aplikasi yang memfasilitasi penggunanya untuk berbagi video, ataupun menikmati berbagai macam video yang diunggah oleh pihak lain.

Video kesaksian juga merupakan salah satu cara yang dapat dilakukan oleh orang percaya untuk mengabarkan kebenaran Injil, salah satu channel video kasaksian yang banyak digemari oleh setiap lapisan masyarakat ialah "Aku dan Sebuah Cerita." Dalam chanel ini, seorang percaya menyampaikan kesaksian perubahan hidupnya ketika berjumpa dengan Yesus Kristus. Hal ini tentu sangat berguna untuk mempercepat pesan Injil itu dapat diterima oleh masyarakat luas. Maka dari itu, salah satu bentuk pelayanan media ini sangat menolong orang percaya dalam menunaikan tugasnya yaitu mengamalkan Amanat Agung hingga ke ujung bumi. Banyak channel rohani yang menggunakan Youtube sebagai salah satu akses untuk berbagi kebenaran Injil, seperti yesHEis Indonesia, JC Channel, Solusi TV, BLESSINGWORD INDONESIA dan lain sebagainya.

\section{Update Status Melalui Facebook}

Salah satu media yang paling banyak digunakan untuk mengupdate sebuah status ialah Facebook. Melalui aplikasi ini, seseorang dapat mengikuti beberapa aktivitas orang lain, melihat foto-foto yang di update dan juga dapat bergabung dalam sebuah group yang berisikan ratusan bahkan ribuan orang. Bukan hanya itu saja, mengingat aksesnya yang tidak terbatas, update status melalui Facebook dapat dimanfaatkan dalam menyampaikan berita Injil kepada orang lain. Pada awalnya Facebook 
membatasi penulisan status dengan maksimal 420 kata. Namun kini, Facebook membolehkan para penggunanya menulis status hingga 63.206 karakter.

Melalui hal tersebut, tentu seseorang yang tergabung dalam aplikasi tersebut bebas untuk mengungkapkan perasaannya dan pendapatnya. Untuk itulah seorang penginjil dapat dengan mudah untuk menuliskan berita Injil untuk di posting ke berandanya. Adrianus Pasasa dalam jurnalnya juga mengungkapkan "Melalui teknologi web, komunikasi sosial yang tersambung secara online, sangat menolong pelayanan pemberitaan Injil dan dapat dilakukan dalam tingkat global maupun lokal. Melalui jejaring sosial, seseorang dapat memberitakan berita Injil selama 24 jam." (Pasasa, 2015, p. 86).

Berdasarkan pendapatnya dapat tersebut, dapat disimpulkan bahwa update status melalui aplikasi Facebook sangat bermanfaat dan berdampak bagi perluasan kerajaan Allah di dunia digital. Para pengguna media sosial ini juga terdiri dari berbagai kalangan usia mulai dari yang muda hingga yang lanjut usia. Oleh sebab itu, bermisi melalui update status Facebook dapat dijadikan sebagai salah satu cara untuk mengkomunikasikan berita Injil di era revolusi industri 4.0 ini.

\section{Update Status Melalui Instagram}

Selain Facebook, salah satu bentuk pelayanan media melalui update status juga dapat dilakukan di sebuah aplikasi yang bernama Instagram. Instagram merupakan media sosial yang cukup digemari oleh 
kaum muda. Ada banyak fitur yang terdapat dalam aplikasi ini seperti Insta Story, direct message, video chat, IG TV, multi akun, caption, saved post, hastag, dan masih banyak fitur lainnya. Insta Story merupakan fitur Instagram yang banyak digemari oleh pengguna Instagram. Dalam fitur insta story seseorang dapat memposting foto, video, lagu, bahkan memberikan question.

Melalui fitur question yang terdapat dalam insta story, seseorang dapat bertanya jawab. Pengguna hanya bisa mengajukan pertanyaan terbuka melalui dua pilihan jawaban yang muncul di opsi sticker, atau pengguna bisa melempar pertanyaan ke pengikutnya di kolom "ask me something" lalu para pengikutnya bisa memberikan respon di kolom "type something." Beberapa pengguna akun rohani sangat gemar menggunakan fitur "question" yang terdapat dalam Insta Story. Hal ini dilakukan dengan tujuan agar pengguna dapat memberikan pertanyaan kemudian para pengikutnya dapat memberikan tanggapan mereka masing-masing.

Itulah beberapa bentuk pelayanan melalui media digital baik update status di media sosial baik Facebook maupun Youtube. Beberapa aplikasi ini dapat digunakan oleh orang percaya dalam hal pemberitaan Injil. Dengan begitu, pesan Injil dapat dengan mudah dibagikan oleh banyak orang sehingga orang yang belum mengenal Yesus dapat mengenal-Nya melalui aplikasi ini. 


\section{KESIMPULAN}

Dengan mengacu pada seluruh pembahasan yang sudah dijelaskan di atas dapat ditarik beberapa kesimpulan bahwa media mengalami perkembangan yang cukup pesat dan dapat memengaruhi setiap lapisan masyarakat tanpa mengenal batas usia. Oleh sebab itu gereja Tuhan perlu bermisi melalui media digital. Sebab pelayanan media cukup berpengaruh besar dalam hal mengkomunikasikan Injil di era revolusi industri 4.0 ini. Bermisi melalui media digital juga sangat berguna untuk menjangkau setiap lapisan masyarakat yang sulit untuk dijangkau karena keterbatasan lokasi dan waktu. Bukan hanya itu saja, setiap lapisan umur dapat dijangkau dengan mudah melalui pelayanan media.

Justin Wise, pendiri Think Digital Academy yang juga adalah pendeta dan ahli strategi media sosial, menyebutkan bahwa Rasul Paulus ketika menulis suratnya dalam Perjanjian Baru menggunakan sebuah pena dan kertas (papirus) yang keduanya adalah tekmologi inovatif pada zaman itu. Martin Luther menggunakan mesin cetak agar firman Tuhan sampai ke tangan orang-orang biasa. Bahkan Billy Graham terkenal karena kebaktian kebangunan rohani dan penginjilannya melalui siaran televisi. Ini berarti bahwa sejak awalnya, gereja menemukan cara untuk menyampaikan berita Injil melalui berbagai macam alat yang tersedia. Sekarang adalah giliran kita untuk menggunakan media sosial untuk menuliskan era berikutnya dalam sejarah gereja. (Stetzer, 2014). 


\section{DAFTAR PUSTAKA}

Arsyad, A. (2013). Media Pembelajaran. Raja Grafindo Persada.

Asosiasi Penyelenggara Jasa Internet Indonesia. (2019). Buletin APJII Edisi 40 - Mei 2019.

Bosch, D. J. . (2009). Transformasi Misi Kristen. BPK Gunung Mulia.

Camerling, Y., \& Wijaya, H. (2019). Misi dan kebangkitan Rohani: Implikasi Misi Allah Bagi Gereja. Jurnal IImiah Religiosity Entity Humanity (JIREH), 1(1), 57-71.

Juditha, C. (2018). Interaksi Komunikasi Hoax di Media Sosial serta Antisipasinya Hoax Communication Interactivity in Social Media and Anticipation. In Jurnal Pekommas (Vol. 3, Issue 1).

MacAvaney, S., Yao, H.-R., Yang, E., Russell, K., Goharian, N., \& Frieder, O. (2019). Hate speech detection: Challenges and solutions. PLOS ONE, 14(8), e0221152. https://doi.org/10.1371/journal.pone.0221152

Mahaney, C. J., Cabaniss, C., Kauflin, B., Harvey, D., \& Purswell, J. (2011). Worldliness: Melawan Godaan Dunia yang Sudah Jatuh Dalam Dosa. Penerbit Pionir Jaya.

Okselviana, A. D., \& Hastjarjo, S. (2016). PENGGUNAAN NEW MEDIA SEBAGAI MEDIA KOMUNIKASI JEMAAT GBI KELUARGA ALLAH SOLO (Studi Kasus Penggunaan New Media Sebagai Media Komunikasi Jemaat GBI Keluarga Allah Solo Tahun 2015). Jurnal Kommas, 1.

Pasande, P., \& Tari, E. (2019). PERAN GEREJA DALAM PENGEMBANGAN PROGRAM KEWIRAUSAHAAN DI ERA DIGITAL. Visio Dei: Jurnal Teologi Kristen, 1(1), 38-58. http://jurnal.sttstarslub.ac.id/index.php/js/article/view/6

Pasasa, A. (2015). PEMANFAATAN MEDIA INTERNET SEBAGAI MEDIA PEMBERITAAN INJIL. Jurnal Simpson, 2(1), 71-98.

Pertiwi, W. K. (2018). Riset Ungkap Pola Pemakaian Medsos Orang Indonesia.

Prasetyo, H., \& Sutopo, W. (2018). INDUSTRI 4.0: TELAAH KLASIFIKASI ASPEK DAN ARAH PERKEMBANGAN RISET. J@ti Undip: Jurnal Teknik Industri, 13(1), 17. https://doi.org/10.14710/jati.13.1.17-26

Pratama, H. C. (2012). Cyber Smart Parenting: Kiat Sukses Menghadapi 
dan Mengasuh GENERASI DIGITAL. PT. Visi Anugerah Indonesia.

Reformed Exodus Community. (2015). Khotbah Streaming: Perlukah? Bolehkah?

Ronda, D. (2016). Pemimpin dan Media: Misi Pemimpin Membawa Injil Melalui Dunia Digital. Jurnal Jaffray, 14(2), 189. https://doi.org/10.25278/jj71.v14i2.210

Sadiman, A. (1993). Media Pendidikan: Pengertian, Pengembangan, dan Pemanfaatannya. Rajawali.

Sanjaya, W. (2014). Media Komunikasi Pembelajaran. Kencana.

Santoso, J. (2017). PERANAN PENGGUNAAN MEDIA DALAM PENGEMBANGAN PELAYANAN KONSELING KELUARGA TERHADAP TANTANGAN KEMAJUAN ILMU PENGETAHUAN DAN TEKNOLOGI (IPTEK). Shift Key: Jurnal Teologi Dan Pengembangan Pelayanan, 7(1). https://doi.org/10.37465/SHIFTKEY.V7I1.3

Stetzer, E. (2014, February). Social Media and Christian Ministry: Reaching the World for the Kingdom of God.

Stott, J. R. W. (1975). Christian mission in the modern world. Intervarsity Press.

Sumarto, Y. (2019). Tinjauan Teologis Tentang Ibadah Bagi Pelaksanaan Misi Allah. Jurnal Jaffray. https://doi.org/10.25278/jj71.v17i1.312

Zacharias, R. (2013). Ravi Zacharias on Twitter. 